Collection: COST Action FP0903 2010 - Rome (Italy)

"Research, monitoring and modelling in the study of climate change and air pollution impacts on forest ecosystems"

Guest Editors: E Paoletti, J-P Tuovinen, N Clarke, G Matteucci, R Matyssek, G Wieser, R

Fischer, P Cudin, N Pototic

\title{
Forest growth and climate change: evidences from the ICP-Forests intensive monitoring in Italy
}

\author{
Bertini G ${ }^{(1)}$, Amoriello $\mathrm{T}^{(2)}$, Fabbio $\mathrm{G}^{(1)}$, Piovosi $\mathrm{M}^{(1)}$
}

\begin{abstract}
A few concurrent and/or counteracting factors (increase of average air temperature, rainfall shortage, drought, $\mathrm{CO}_{2}$ enrichment, ozone, nitrogen fertilization, sulphate deposition) drive today the soil-tree-atmosphere relationships in the Mediterranean area. Radial stem growth measured within the ICPForests level II Italian network provides a sensitive response to these occurrences. Climate fluctuations and repeated anomalous seasons or extreme events are the major evidences of the change in progress. The 2003 heat wave is the main event occurred in this decade over large part of Europe. In Italy, it provoked a marked water deficit coupled to high air temperature, which resulted in a heavy water stress. The growth performance in different forest types was analyzed in this paper: growth rate in 2000-2004, compared with 19971999 , showed reductions up to $50 \%$ on half of the plots examined. Most of them were: (i) in northern-central Italy within the southern continental border of the climatic deviation; (ii) at low elevation, which is more sensitive to high air temperature and drought; (iii) made up of deciduous broadleaved forests (beech and oaks), i.e., species showing growth effects also in the following year. Over the time-window 2005-2009, a significant growth decrease was vice-versa detected within the coniferous spruce forests located at medium-high elevation in the Alps. Repeated seasonal deviations in temperature and rainfall were recorded in the Alps in 2005-2009. Climate effects at local scale were examined in a site where two oak species with a different auto-ecology (sessile oak and Turkey oak) grow together. The on-going change produced heavy mortality and reduced the growth of the more demanding and less drought-tolerant sessile oak; in a few years Turkey oak became prevailing in the stand composition and structure.
\end{abstract}

Keywords: Climate fluctuations, Extreme events, Monitoring, Stem growth

\section{Introduction}

Trees react to environmental changes within their auto-ecological tolerance and search for a new equilibrium. Climate change, acts as a driving force on ecosystem processes with direct and indirect feedbacks (Bortoluzzi 2000). Further concurrent or counteracting factors, i.e., $\mathrm{CO}_{2}$ enrichment, ozone level, nitrogen fertilization, sulphates deposition, drive today the soil-tree-atmosphere relationships (Augustin 2009, Lorenz \& Granke 2009, Lundin 2009, Requardt et al. 2009, Schaub 2009, Serengil et al. 2011) and the specific tree growth within each geographical area. As a feedback, changes in patterns of tree growth can have a huge impact on atmospheric and biogeochemical cycles, climate change, and biodiversity (McMahon et al. 2010). The environmental changes also affect forests indirectly via the occurrence of diseases, pathogens and insect outbreaks (Hemery 2007, Eastaugh 2008, Chakraborty et al. 2008).

Mediterranean forests are particularly sensitive to global change (Scarascia-Mugnozza et al. 2000, De Angelis et al. 2005, Ferretti et al. 2008). Future scenarios predict an increase in drought stress (with increased temperature and decreased precipitation) throughout Europe (e.g., the 2003 heat wave - Rebetez et al. 2006), the Mediterranean region being particularly affected. The climatic trends in the area during the last 50 years have been characterized by a rise in mean temperature $\left(2-4^{\circ} \mathrm{C}\right)$ and an increase in both frequency and intensity of severe droughts (IPCC 2001, 2007). Drought is one of the most important factors triggering both tem- $\square$ (1) Centro di Ricerca per la Selvicoltura CRA-SEL, Arezzo (Italy); (2) Consiglio per la Ricerca e la Sperimentazione in Agricoltura, Roma (Italy)

@ Giada Bertini (giada.bertini@entecra.it)

Received: Nov 26, 2010 - Accepted: Aug 12, 2011

Citation: Bertini G, Amoriello T, Fabbio G, Piovosi M, 2011. Forest growth and climate change: evidences from the ICP-Forests intensive monitoring in Italy. iForest 4: 262267 [online 2011-12-13] URL:

http://www.sisef.it/iforest/contents/? id=ifor0596-004

porary declines and mortality in temperate forests (Innes 1994).

Current climate change is made by longterm variations in average parameters, as well as by the increased occurrence of anomalous years and extreme events. Whilst the long-term effects require extended data sets, the consequence of anomalies (usually one season, one year as a maximum) can be traced in the short-term. Tree growth, a quantitative indicator of tree vitality and ability to buffer environmental constraints (Dobbertin 2005), provides a sensitive response to impacts. Forest growth is among the parameters measured within the intensive (level II) forest monitoring of UN/ECE ICPForests (International Co-operative Programme on Assessment and Monitoring of Air pollution effects on Forests), aimed at analyzing the effects of air pollution and other stress factors on the conditions of forests in Europe (Lorenz et al. 2004). The programme, now focused on climate change, ozone effect on forests and biodiversity loss (Petriccione 2008), was carried out (20092010) under the LIFE+ Futmon project.

Aims of this paper are to: (1) examine radial stem growth at ICP-Forests level II plots in Italy over the last 13 years (1997-2009); (2) find out the impact of the 2003 heat wave; (3) highlight the growth trend and occurrence of regional climate fluctuations over the period 2004-2009; (4) analyze the impact of climate deviations on stand structure and specific composition at a case study.

\section{Materials and methods}

The data set was made up of 31 plots, divided into four main types, i.e., beech high forests (A), spruce forests (B), beech and oak coppice forests $(\mathrm{C})$, and transitory crops, i.e., coppice forests undergoing conversion into high forest (D). Detailed information on sites and stand characteristics are reported in Fabbio \& Amorini (2000, 2002), Fabbio et al. (2006, 2008) and Petriccione (2008). Status and change in key meteorological variables up to 2005 are in Amoriello \& Costantini 
(2008). The analysis of meteorological elements, i.e., mean air temperature and precipitation, was updated to 2009 .

Individual tree measurements were carried out over the dormant season in 1996-97, 1999-2000, 2004-2005, and 2009-2010. Tree size and its change at plot level were used as response variable. Growth was expressed as basal area (b.a.) and basal area increment (b.a.i.); growth variation over time was computed as annual b.a.i. as percent of b.a. at the beginning of each growth period. The percentage ratio between subsequent b.a.i. (2000-2004 vs. 1997-1999 and 20092005 vs. 2000-2004) was used to assess evidence and magnitude of growth variation. Growth reduction was ranked as 1 to $15 \%$, 15 to $30 \%$, more than $30 \%$.

A case study (plot EMI1) located at the southern border of the Po Valley (northern Italy) was selected because of the presence of two deciduous oaks, Quercus cerris (Turkey oak) and $Q$. petraea (sessile oak), with a different auto-ecology. Climatic series and tree ring chronologies were available since 1977 (Bertini \& Amoriello, internal report 2009). Ring widths were measured to the nearest $0.01 \mathrm{~mm}$ on cores from 20 dominant trees for each species, using LEGA Dendrochronograph SMIL 3 equipment and software package (SMIL 3.1 - Manetti et al 2003). Both the species being aged likewise, the analysis was performed on raw datasets without any indexing (Fritts 1976).

\section{Results and discussion}

Tree growth-climate relationships at regional level

The overall growth in terms of b.a.i. was

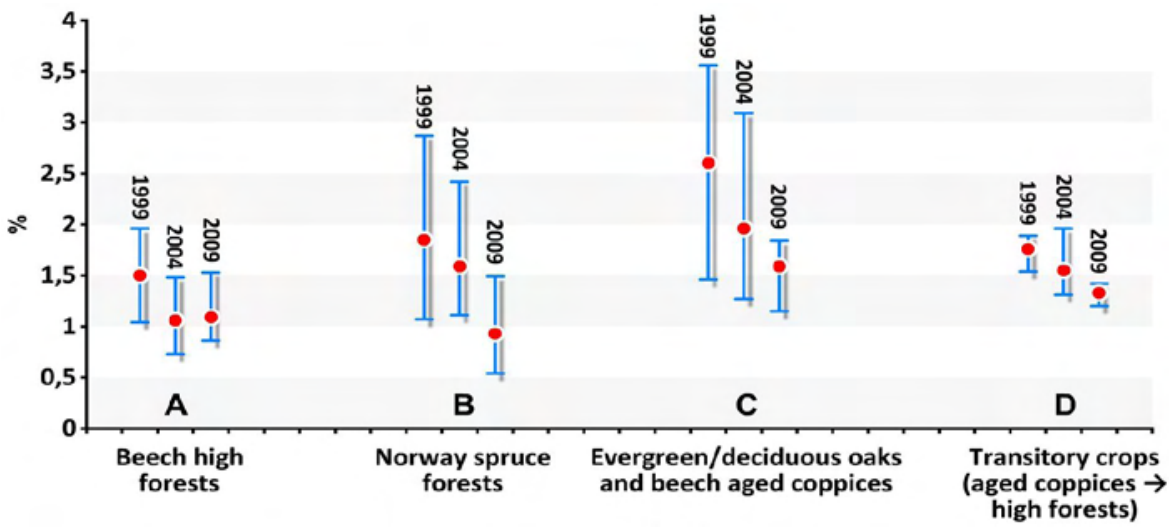

Fig. 1 - Mean and range of periodical basal area increment as percent of basal area at the beginning of each period per forest type (A-D) and inventory (1999-2004-2009).

between 0.5 and $3.5 \%$ (Fig. 1). Growth rate differed depending on forest type, i.e., coppice forests $>$ transitory crops $>$ spruce forests $>$ beech high forests. Changes occurred even within each type at different inventories, with an overall trend toward growth reduction.

In central Europe, a number of studies have shown increasing forest growth over the last 15 years rather than a decline as was expected due to negative effects of air pollution (Solberg et al. 2009, Laubhann et al. 2009). In contrast, the extreme drought of 2003 led to a reduction of forest growth in low-land forests (up to 60\%), whilst high altitude forests showed no growth change or increased growth (Jolly et al. 2005, Dobbertin et al. 2006).

A growth reduction (Fig. 1) was observed in Italy for each forest type in the period 1999-2004; a further, minor decrease, not equally distributed over the types, was also detected in the period 2005-2009. Beech forests (A) showed a steady growth rate following the former reduction, whilst spruce forests (B) showed again a clear drop, with types $\mathrm{C}$ and $\mathrm{D}$ showing minor changes. In 2005-2009, the variability of growth was lower in all types than in the previous periods, suggesting a common disturbance.

In the period 2000-2004 (Fig. 2), a marked growth reduction (more than 30 and up to $50 \%$ ) was observed on about half of the plots (red-labelled in the figure), all of them being located within the southern border of the 2003 heat wave. Most of plots were at low elevations and made up of deciduous broadleaved forests (oaks and beech), i.e., tree species characterized by a predetermined early growth. This feature means that an anomalous event in the growing season $\left(i^{\text {th }}\right)$ will also affect the early growth of the

Fig. 2 - ICP-Forests level II network in Italy and growth reductions measured over 2000-2004 at each plot.





in Italy and growth reductions measured over 2005-2009 at each plot.
Fig. 3 - ICP-Forests level II network

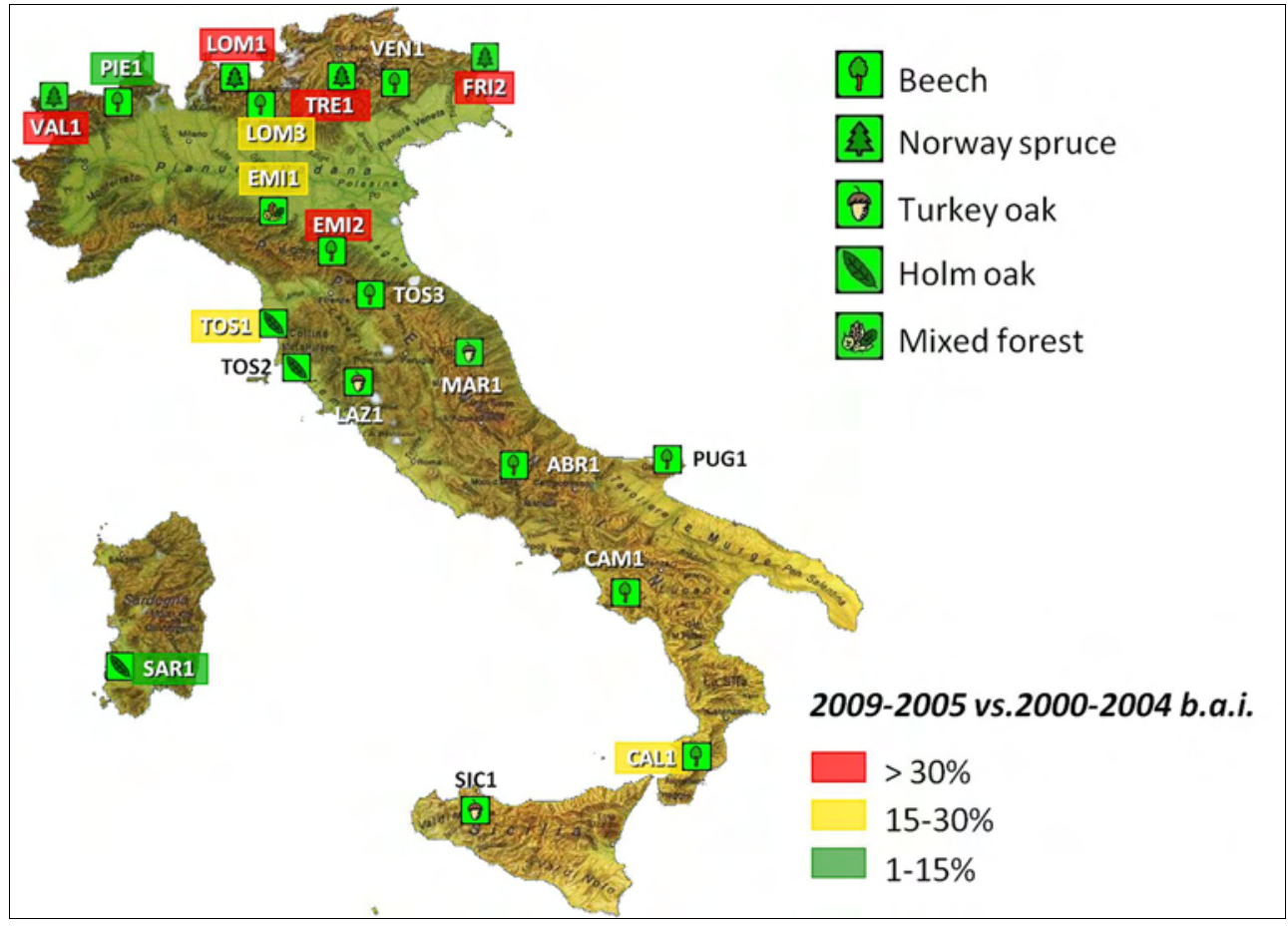

2006, Ciais et al. 2005, Leuzinger et al. 2005).

Climate anomalies occurred also before 2003; both 2000 and 2002 were very rainy years; a long dry period occurred in 2000 in
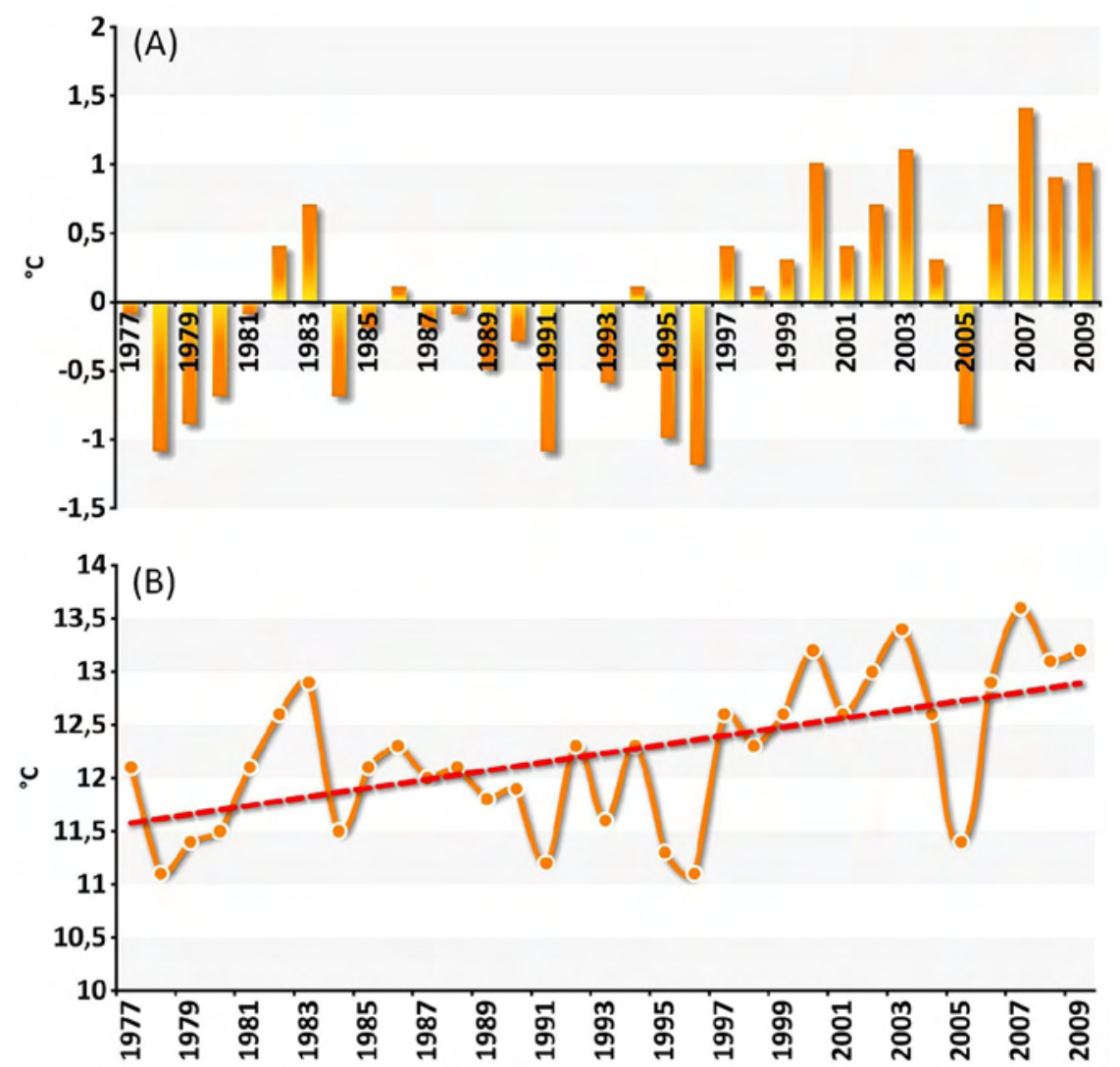

Fig. 4 - Deviations and trend of mean annual air temperature at a case study plot (EMI1). (A): deviation from mean AT (1977-2009); (B): Mean AT (1977-2009). northern Italy (January-February) followed by a cool and rainy summer in 2002 all over the country (Amoriello \& Costantini 2008).

Over the last time-window (2005-2009), the more significant growth decrease was detected in the Alpine area where quite all the locations were spruce forests at medium-high elevations (Fig. 3). The analysis of climate regime over the Alpine area and northern Italy highlighted a few anomalies: a very cold winter in 2004-2005; a warm winter in 2006-2007 with the persistence of high air temperature up to late spring; a dry autumn in 2007; an unusual rise of air temperature in January-February 2008; and a rainy winter in 2008-2009 with heavy rainfalls up to mid spring. The repeated occurrence of seasonal deviations seems therefore the rule over the last decade in the Alps, in accordance with climate models of IPCC for the area (Bertini et al. unpublished).

Tree growth-climate relationships at level of a case-study

The plot EMI1, facing the southern border of the Po valley, is an interesting case study because two deciduous species with different ecological requirements - Turkey oak and sessile oak - grow together at the same site. as both over mature, large-sized trees and regeneration cohorts occur in the neighbourhood. No limiting factors to this oak are therefore evident at the site. Sessile oak, a mesophytic species, needs relatively high moisture content in the air and in the soil and at least a rainfall of $120 \mathrm{~mm}$ over the growing season. Turkey oak, a relatively drought-tolerant species, stands up to 2-4 The presence of sessile oak is not residual, 

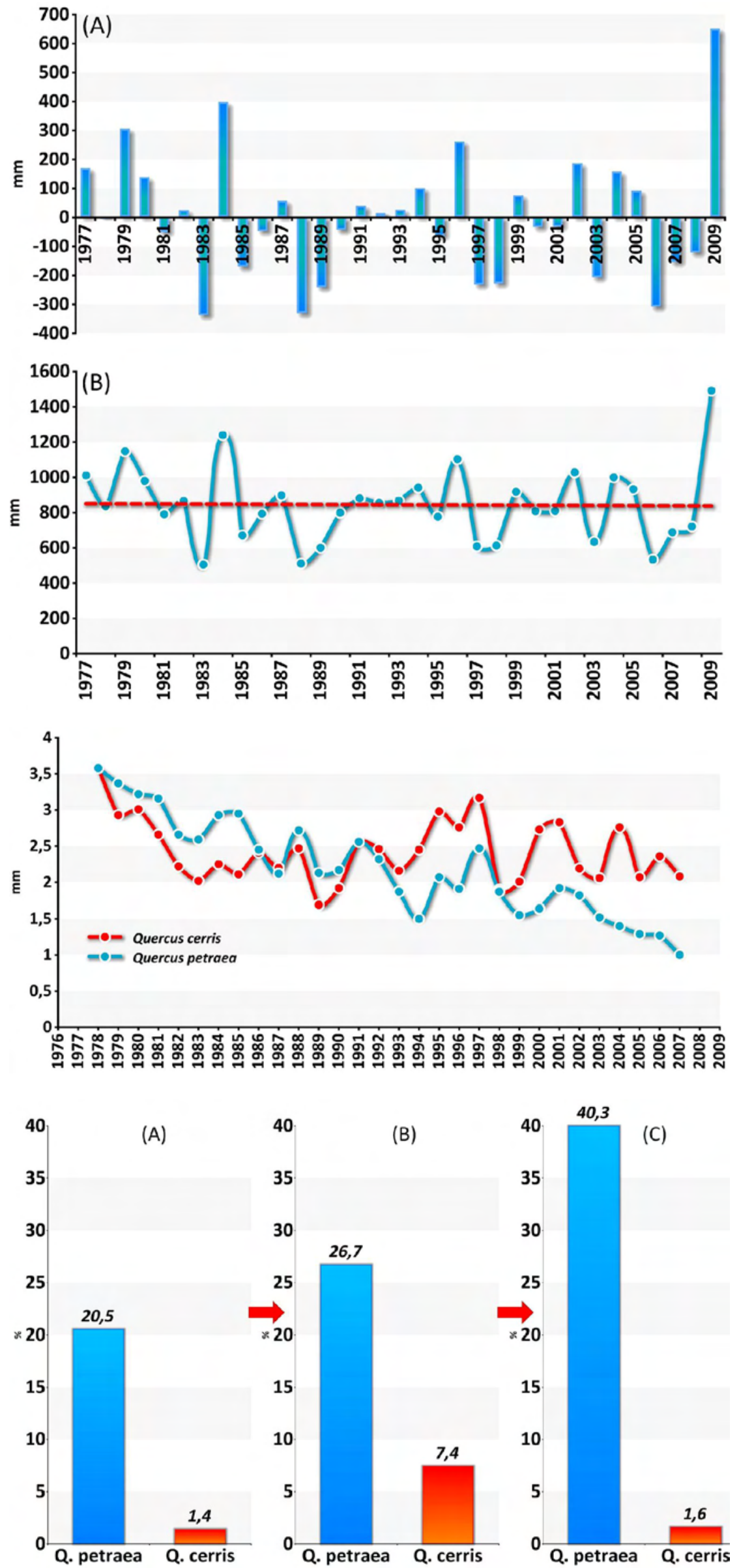

iForest (2011) 4: 262-267
Fig. 5 - Deviations and course of mean annual rainfall at EMI1. (A): deviation from mean PR (1977-2009); (B): mean PR (1977-2009).

Fig. 6 - Tree ring widths mean chronologies of oak species at EMI1.

Fig. 7 - Tree mortality (\% of stem number) of oak species at EMI1. (A): years 1997-2000; (B): years 2000-2005; (C): years 2005-2010. 
(A)
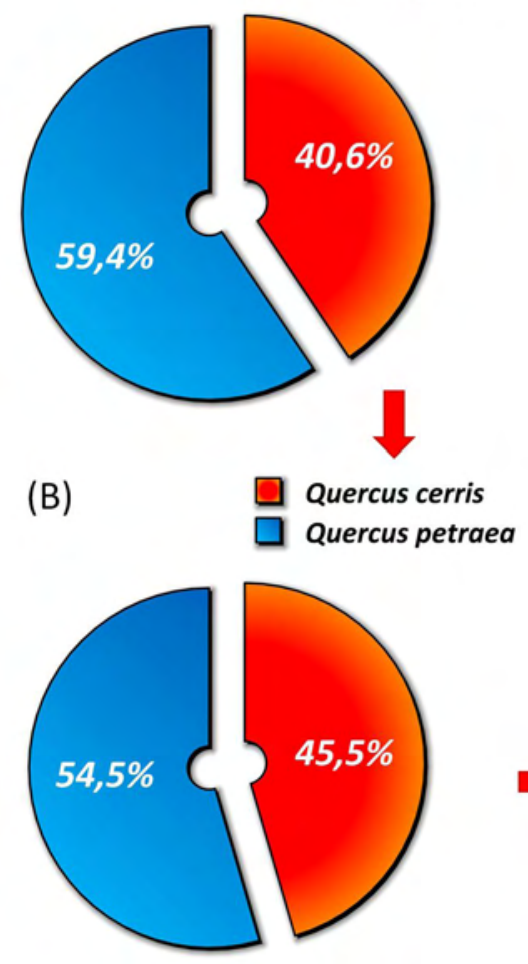

(D)



(C)



Fig. 8 - Variation of species composition in terms of \% basal area over the inventories at EMI1. (A): year 1997; (B): year 1999; (C): year 2004; (D) year 2009.

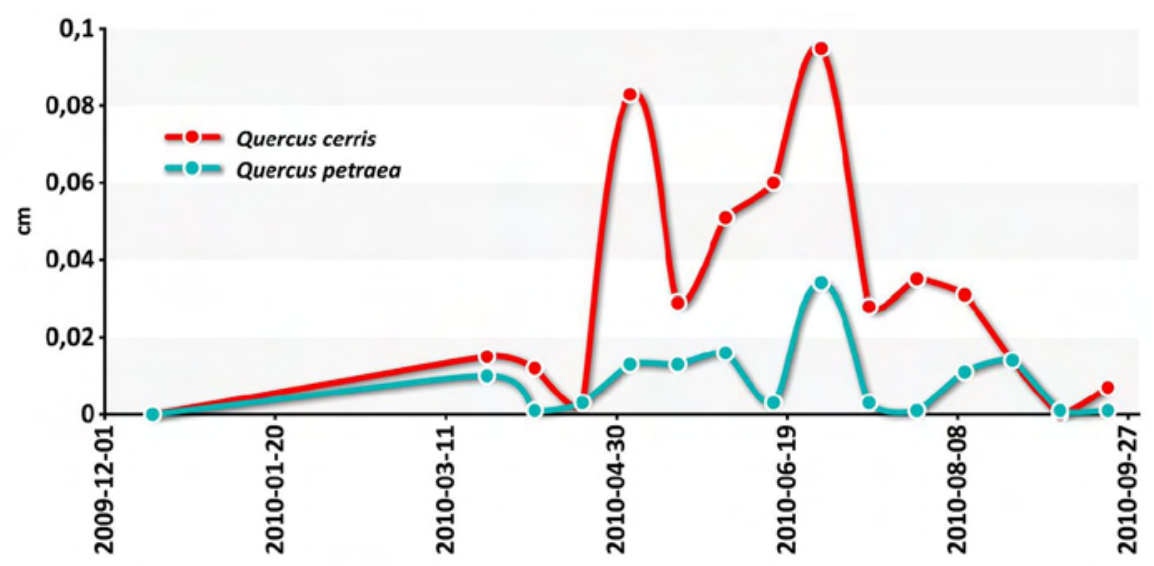

Fig. 9 - Intra-annual radial growth (2010) of the oak species at EMI1.

consecutive months with reduced rainfall $(<40 \mathrm{~mm})$ and up to 4 months of drought. A 30 -year climatic series (1977-2009) at this site showed repeated occurrence of deviations from the mean annual air temperature and rainfall, and an increase of mean air temperature over time (Fig. 4 and Fig. 5).

The raw mean chronologies of tree ring widths for the two same-age oak species showed a declining course in sessile oak (Fig. 6), i.e., the species that is more affected by drought and increased air temperature, suggesting a persistent water stress over the growing season. The resulting tree mortality (in terms of number of stems) over the following inventories affected sessile oak much more than Turkey oak (Fig. 7).

The shift towards a less favourable growth environment for the more demanding species resulted in a heavy change in structure and species composition as well. Sessile oak was the most abundant species in the stand at the beginning of the monitoring period i.e., in 1997 (59\% b.a.), while in 2009 it was less abundant (39\%) than Turkey oak, because the latter species was much less affected by the ongoing drier conditions (Fig. 8).

Intra-annual stem growth measurements by permanent tree-girth tapes highlight the radial growth pattern of each species (Fig. 9). The seasonal course was synchronous, but the growth rate was lower in sessile oak than in Turkey oak over the whole spring-summer period.

These results confirm an increased frequency of extreme drought events, potentially leading to dramatic reductions in wood productivity and changes in species composition and structure (Le Blanc \& Foster 1992, Graumlich 1993, Ciais et al. 2005).

\section{Conclusions}

In addition to atmospheric chemistry, current climate fluctuations, recurrent anomalous years and extreme events throughout Europe are the main driving forces acting on forest health and vitality. The effects are registered in tree growth, a sensitive signal of tree condition. Unravelling and quantifying these complex interactions on forests is further complicated by changes at different latitudes, elevations and according to the species sensitivity. Recognizing the effect of each pressure, identifying possible feedbacks and the onset of limiting factors seem to be the priority issues today. Monitoring activity can play this role and highlight different impacts at different scales, as in the present case.

\section{Acknowledgements}

The authors wish to thank Bruno Petriccione and Enrico Pompei, National Forest Service (CFS), the technical staff of the $\mathrm{Na}-$ tional Forest Service, the territorial administrations and Regional parks working at the plots, Angelo Vanini, Antonia Cavalieri and Nicola Donetti at Parco Regionale "Boschi di Carrega" (EMI1), for their professional and helpful field assistance.

The monitoring activity is currently funded within the project LIFE+ ENV/DE/000218 "FUTMON".

\section{References}

Amoriello T, Costantini A (2008). Status and changes in key meteorological variables at the CONECOFOR plots, 1996-2005. Annali Centro di Ricerca per la Selvicoltura 34: 73-84.

Augustin S (2009). Linking critical threshold for acidity to forest condition by using element contents in tree rings: consequences for the development of an integrated ecosystem assessment. iForest 2: 51-53. - doi: 10.3832/ifor0473-002

Bortoluzzi B (2000). Review of recent forest research projects on climate change and $\mathrm{CO}_{2}$ concentration in Europe. EFI Internal Report 01/2000, European Forest Institute, Joensuu, Finland. [online] URL: http://www.efi.int/files/ attachments/publications/ir_01.pdf 
Chakraborty S, Luck J, Hollaway G, Freeman A, Norton R, Garrett KA, Percy K, Hopkins A, Davis C, Karnosky DF (2008). Impacts of global change on diseases of agricultural crops and forest trees. Perspectives in Agricultural, Veterinary Science, Nutrition and Natural Resources 3 (054): 1-15.

Ciais PH, Reichstein M, Viovy N, Granier A, Ogée J, Allard V, Aubinet M, Buchmann N, Bernhofer Chr, Carrara A, Chevallier F, De Noblet N, Friend AD, Friedlingstein P, Grunwald T, Heinesch B, Keronen P, Knohl A, Krinner G, Loustau D, Manca G, Matteucci G, Miglietta F, Ourcival JM, Papale D, Pilegaard K, Rambal S, Seufert G, Soussana JF, Sanz MJ, Schulze ED (2005). Europe-wide reduction in primary productivity caused by the heat and drought in 2003. Nature 437: 529-533. - doi: 10.1038/ nature 03972

De Angelis P, de Dato G, Spano D, Duce P, Sirca C, Asunis C, Pellizzaro G, Cesaraccio C, Sechi S, Scarascia Mugnozza G (2005). Una nuova area sperimentale di lungo termine, per lo studio degli effetti dell'incremento della temperatura e del periodo di aridità in formazioni di sclerofille mediterranee. Forest@ 2 (1): 37-51. - doi: 10.3832/efor0260-0020037

Dobbertin M (2005). Tree growth as indicator of tree vitality and of tree reaction to environmental stress: a review. European Journal of Forest Research 124: 319-333. - doi: 10.1007/s10342005-0085-3

Dobbertin M, de Vries W, Sterba H (2006). Response of forest ecosystems to changing environmental conditions. In: Proceedings of the Meeting "Forests in a Changing Environment". Gottingen (The Netherlands) Oct 25-28 2006. [online] URL: http://www.icp-forests.org/DocsCrown/Go2_Dobbertin.pdf

Eastaugh C (2008). Adaptations of forests to climate change: a multidisciplinary review. IUFRO Occasional Paper \#21, IUFRO Secretariat, Vienna, Austria, pp. 83. [online] URL: http://www. ibcperu.org/doc/isis/9117.pdf

Fabbio G, Amorini E (2000). Tree growth survey and increment assessment. Contribution to the integrated evaluation of ecosystem's status. Annali Istituto Sperimentale per la Selvicoltura 30: 81-89.

Fabbio G, Amorini E (2002). Contribution to growth and increment analysis on the Italian CONECOFOR Level II network. Journal of Limnology 61 (1): 46-54.

Fabbio G, Manetti MC, Bertini G (2006). Aspects of biological diversity in the CONECOFOR plots. II. Species richness and vascular plant diversity over the period 1999-2003. Annali Istituto Sperimentale per la Selvicoltura 30 (2): 17 28.

Fabbio G, Bertini G, Calderisi M, Ferretti M
(2008). Status and trend of tree growth and mortality rate at the CONECOFOR plots, 19972004. Annali centro di ricerca per la selvicoltura 34: 11-20.

Ferretti M, Bussotti F, Fabbio G, Petriccione B (2008). Status and changes in key ecosystem attributes monitored at the CONECOFOR plots, 1995-2005 - Achievements, problems, perspectives. Annali Centro di Ricerca per la Selvicoltura 34: $115-120$.

Fritts HC (1976). Tree rings and climate. Academic Press, London, New York, San Francisco, USA, pp. 567.

Graumlich LJ (1993). Response of tree growth to climatic variation in the mixed conifer and deciduous forests of the upper Great Lakes region. Canadian Journal of Forest Research 23: 133143. - doi: 10.1139/x93-020

Hemery GE (2007). Forest management and silvicultural responses to predicted climate change impacts on valuable broadleaved species. ShortTerm Scientific Mission report for Working Group 1, COST Action E42, pp. 196. [online] URL: http://www.valbro.uni-freiburg.de/pdf/ stsm_hemery.pdf

Innes JL (1994). Climatic sensitivity of temperate forests. Environmental Pollution 83: 237-243. doi: 10.1016/0269-7491(94)90038-8

IPCC (2001). Climate change 2001: the scientific basis. Contribution of working group I to the third assessment report of the intergovernmental panel on climate change. Cambridge University Press, Cambridge, UK.

IPCC (2007). Climate change 2007: the physical science basis. Contribution of working group I to the fourth assessment report of the intergovernmental panel on climate change. Cambridge University Press, Cambridge, UK.

Jolly WM, Dobbertin M, Zimmerman NE, Reichstein M (2005). Divergent vegetation growth responses to the 2003 heat wave in the Swiss Alps. Geophysical Research Letters 32: L18409. - doi: 10.1029/2005GL023252

Laubhann D, Sterba H, Jan Reinds G, de Vries W (2009). The impacts of atmospheric deposition and climate on forest growth in European monitoring plots: an individual tree growth model. Forest Ecology and Management 258 (8): 17511761. - doi: 10.1016/j.foreco.2008.09.050

Le Blanc DC, Foster JR (1992). Predicting effects of global warming on growth and mortality of upland oak species in the midwestern United States: a physiologically based dendroecological approach. Canadian Journal of Forest Research 22: 1739-1752. - doi: 10.1139/x92-228

Leuzinger S, Zotz G, Roman A, Körner C (2005). Responses of deciduous forets trees to severe drought in Central Europe. Tree Physiology 25: 641-650. [online] URL: http://treephys.oxfordjournals.org/content/25/6/641.full.pdf
Lorenz M, Granke O (2009). Deposition measurements and critical loads calculations: monitoring data, results and perspective. iForest 2: 11-14. doi: 10.3832/ifor0478-002

Lorenz M, Becher G, Mues V, Fischer R, Ulrich E, Dobbertin M, Stofer S (2004). Forest condition in Europe - 2004 Technical Report. UN/ECE, Geneva, Switzerland.

Lundin L (2009). Hydrology, element budget, acidification, nutrient $\mathrm{N}$ in a climate change perspective for the northern forest region. iForest 2 : 23-25. - doi: 10.3832/ifor0479-002

Manetti MC, Bertini G, Pichi M (2003). SMIL 3.1 - Sistema di misurazione degli incrementi legnosi: un programma per l'indagine incrementale di sezioni trasversali e per l'analisi del fusto. Annali Centro di Ricerca per la Selvicoltura 31: 65-71.

McMahon SM, Parker GG, Miller DR (2010). Evidence for a recent increase in forest growth. Proceedings of the National Academy of Sciences USA 107 (8): 3611-3615. - doi: 10.1073/ pnas.0912376107

Petriccione B (2008). The CONECOFOR programme from 1995 to 2005. Annali centro di ricerca per la selvicoltura 34: 3-10.

Rebetez R, Mayer H, Dupont O, Schindler D, Gartner K, Kropp JP, Menzel A (2006). Heat and drought 2003 in Europe: a climate synthesis. Annals of Forest Science 63: 569-577. - doi: 10.1051/forest:2006043

Requardt A, Schuck A, Kohl M (2009). Means of combating forest dieback- EU support for maintaining forest health and vitality. iForest 2: 3842. - doi: 10.3832/ifor0480-002

Scarascia-Mugnozza G, Oswald H, Piussi P, Radoglou K (2000). Forests of the Mediterranean region: gaps in knowledge and research needs. Forest Ecology and Management 132: 97-109. doi: 10.1016/S0378-1127(00)00383-2

Schaub M (2009). Future monitoring and research needs for forest ecosystems in a changing environment: an introduction. iForest 2: 54-55. - doi: 10.3832/ifor0488-002

Serengil Y, Augustaitis A, Bytnerowicz A, Grulke N, Kozovitz AR, Matyssek R, Müller-Starck G, Schaub M, Wieser G, Coskun AA, Paoletti E (2011). Adaptation of forest ecosystems to air pollution and climate change: a global assessment on research priorities. iForest 4: 44-48. doi: 10.3832/ifor0566-004

Solberg S, Dobbertin M, Jan Reinds G, Lange H, Andreassen K, Garcia Fernandez P, Hildingsson A, de Vries W (2009). Analyses of the impact of changes in atmospheric deposition and climate on forest growth in European monitoring plots: a stand growth approach. Forest Ecology and Management 258 (8): 1735-1750. - doi: $10.1016 /$ j.foreco.2008.09.057 